\title{
Operating SMEs in the Face of the COVID-19 Pandemic in Calabar
}

\author{
Mary U. Ojong-Ejoh ${ }^{\mathrm{a}}$, Pius U. Angioha ${ }^{\mathrm{a}}$, Rose U. Agba ${ }^{\mathrm{a}}$, Evaristus A. Aniah ${ }^{\mathrm{a}}$, Maruf Gbadebo \\ Salimon $^{\mathrm{b}} \&$ Abayomi Akintola ${ }^{\mathrm{a}}$ \\ ${ }^{a}$ Department of Sociology, University of Calabar, Nigeria \\ ${ }^{b}$ School of Business Management, Universiti Utara Malaysia, Sintok, Kedah, Malaysia
}

\begin{abstract}
This study examines the impact of the COVID-19 pandemic on small and medium scale enterprise Operation in Calabar, Cross River State, Nigeria. The cross-sectional survey method was used in collecting data from 474 SMEs in Calabar, Cross River State using the stratified and purposive sampling technique. The instrument of data collection was a self-developed semi-structured questionnaire. Data collected from the field was coded, analyzed using descriptive statistics such as tables and graphs and correlation analysis at 0.05 level of significance. Out of the 474-instrument distributed only 422 was returned and used for analysis. From the analysis, the result revealed that 88.6 per cent of the SMEs reported being negatively affected by the pandemic, 71.3 per cent reported laying off employees during this period. Also result from the correlation analysis revealed that there is a significant relationship between COVID-19 pandemic and the operations of SMEs in Calabar, Cross River State, Nigeria. Based on these findings, there is a need for policy adjustment toward SMEs operations in Calabar.
\end{abstract}

Keywords: COVID-19; pandemic; SMEs; Employment; Measures; Calabar.

\section{Introduction}

In today's global economy, small and medium enterprises have been recognized as a driver of economic growth and contribute immensely to the wellbeing of nations especially developing nations. According to the Organization for Economic Co-Operation and Development (2019), small and medium enterprises accounts for 99 per cent of global business and 50 per cent of global employment. In developing economy, formal SME's accounts for up to 40 per cent of the Gross Domestic Product (World Bank, 2020). Almost two in every three persons is employed by an SME (OECD, 2019). In Africa, small and medium scale enterprises make up to 60 per cent of the continent's business and 60 per cent of its population of employable age are employed by small business (International Trade Centre, 2018). In one of the continent's biggest economy, South Africa, SMEs makeup 91 per cent of its business and contributes to 52 per cent of the nation's Gross Domestic Product.

In Nigeria, the National Bureau of Statistics (2019) report that small and medium enterprise accounts for 48 per cent of the nation's gross domestic product, 84 per cent of the nation's employment. The NBC (2019), reported that there are about 17.4 million SMEs in Nigeria, accounting for up to 50 per cent of all industrial jobs and 90 per cent of all manufacturing jobs (Saidu \& Aifuwa, 2020). The NBC (2019) reports that in the next five years that SMEs is strategically placed to provide 80 per cent of the country's jobs, improve the per capita income, increase the valueadded to raw materials and expand the country's economy. The International Monetary Fund (2019) estimated that SMEs will contribute 3.3 per cent to global growth in 2020. But the COVID-19 pandemic has hindered this contribution.

\footnotetext{
* Corresponding author.

E-mail address: uyiejoh@gmail.com (Mary U. Ojong-Ejoh)
} 
In the past eight months, the world has been faced with its most chronic problem since the second world war. The novel cov-sar-2 virus, popularly known as coronavirus or COVID-19 has become undoubtedly the greatest health catastrophe of this generation and continue to throw several challenges for mankind. As more and more cases sprang up every day and the rising death toll continue to cause widespread panic in this trying time (Nicola, Alsafi, Sohrabi, Kawan, Al-jabir, Iosifidis, Agha \& Agha, 2020; Iji, Ojong, \& Angioha, 2018; Omang, Angioha, Ojong-Ejoh \& Abang, 2020). The scale of the impact of the COVID-19 pandemic is unprecedented and evidence from studies carried out globally suggested it might take decades for the world to recover from its impact (Ali, \& Alharbi, 2020; Yuki, Fujiogi \& Koutsogiannaki, 2020; Omang, \& Angioha, 2021; Akintola, Angioha, Abang \& Etta, 2020)

Apart from the health hazard and the human life consequences of the pandemic, the socioeconomic uncertainties and disruption from the measures put in place by the various government have come at a serious cost to the global economy (Akanmi, \& Gabriel,2020). UCTAD (2020) report that the coronavirus pandemic will cause recession in some nations especially the most affected and will depress the annual global economic growth by 2.5 per cent. The report also reported 2.2 trillion dollars fall in income globally. One of the most affected sectors is small and medium enterprises (Eggar, 2020; Syriopoutous, 2020).

The survey by International Organization for Migration (2020) on 456 enterprises of different sectors in Iraq found that the COVID-19 pandemic has a significant impact on the economic outcome of SMEs at both production and sale level. The impact has been significant on the manufacturing, construction, food and agriculture industry. The survey by the Economic Policy Research Centre (EPRC) (2020) revealed that three-quarters of SMEs surveyed has laid off their workers because of the measures put in place to curb the spread of the COVID-19. The Survey by Bartik, Bertrand, Cullen, Glaeser, Luca and Stanton (2020) On 5800 small businesses that are registered under the alignable revealed that the coronavirus pandemic has caused dislocation among SMEs. 43 per cent of the surveyed SMEs reported temporary closure as a result of the measures in place to check the spread of the pandemic. Averagely, SMEs reported reducing their workforce by 39 per cent since the pandemic began. The Sun Business Network (2020) assessed the impact of the COVID-19 pandemic and its associate factors on business. 363 surveyed response was retrieved, 94 per cent of survey businesses report a decrease in sales.

In Nigeria, the number of new infections continues to rise and the government continue to look for new measures to curb the spread of the coronavirus. Since the first case was reported and the various measures such as quarantine and lockdown measures to curb the spread of the virus, the most affected sector of the Nigerian economy is SMEs. This is because the sector provides 48per cent of the nation's GDP and provides 84 per cent of the national employment. With the domestic restriction to curb the spread of the virus, most small businesses have had to stop operation, close down or reduce or alter their mode of operations. The availability of raw materials and production have become very challenging (Onyinyechukwu,2020). There is little empirical evidence of the extent to which the covid -19 has affected the development of SMEs in Nigeria. This study examines the extent to which covid -19 measures have affected the operation of SMEs in Calabar Cross River State, Nigeria.

\section{Methods}

\subsection{Study Settings}

Calabar the study area is located in the southern part of Cross River State, Nigeria the area is flanked on its western and eastern border by the Calabar River and Great Kwa River respectively. Calabar covers an area of 406 square kilometres. set up as the centre of trade by the British in the $17^{\text {th }}$ century, the city is set in a hilltop overlooking the Calabar River. Calabar acts as the capital of cross river state and for administrative purposes is divided into Calabar South and Calabar Municipal Council. As a coastal town, Calabar has a high relative humidity around 80per cent and 100per cent. According to National Population Commission (2006), the population of Calabar is 371,022. As the administrative capital of Cross River State, Calabar draws a large population of business owners and civil servants. Farming, hunting and fishing remain an occupation of some residents (Angioha, Nwagboso, Ironbar \& Ishie, 2018). 


\subsection{Study Method}

The cross-sectional survey design was adopted for this study. The design involves examining data collected from a population or a subset of it at a particular point in time to determine a causal relationship between variables of interest (Adah, Angioha, Ugwuonwu, \& Akomaye, 2020; Angioha, Omang, Ishie, \& Iji, 2020). For this study, the qualitative method of data collection was used in using the questionnaire method a self-developed semi-structured questionnaire was used to elicit information from the respondents.

\subsection{Sampling}

474 Samples was used from the population of Calabar. The Survey Monkey Sampling Determinant Technique was used to determine the sample size at 95 per cent confidence level and margin of error of 4.5 per cent. The stratified and purposive sampling technique was used to selecting the sample size from the study area. Calabar was stratified into two strata based on the local government area. Calabar South and Calabar Municipal Council. From these local government areas, four wards were selected from each of the local government areas. The ward selected are highlighted in table 1 from this wards, 2 areas were selected using purposive sampling technique. from these areas, 30 small business owners were purposively selected from 10 of the areas and 29 from 6 areas.

Table 1. Sample Selection from Calabar

\begin{tabular}{|c|c|c|c|}
\hline $\mathbf{S} / \mathbf{N}$ & Local Government Area & Wards & Communities and Sample size \\
\hline \multirow[t]{8}{*}{1} & Calabar South & 9 & Palm street (30) \\
\hline & & & Mayne avenue (30) \\
\hline & & 11 & Afokang (29) \\
\hline & & & Mbukpa (30) \\
\hline & & 12 & Ekpo Abasi (30) \\
\hline & & & Mayne Avenue 29) \\
\hline & & 4 & lagos street (30) \\
\hline & & & Edgerley (30) \\
\hline \multirow[t]{8}{*}{2} & Calabar Municipal Council & 2 & Edim Otop (30) \\
\hline & & & Otu Ansa (39) \\
\hline & & 4 & Atekong (30) \\
\hline & & & big qua (29) \\
\hline & & 8 & Federal Housing (29) \\
\hline & & & Ikot Ansa (29) \\
\hline & & 1 & Etta agbor (30) \\
\hline & & & Goldie/mayne avenue (30) \\
\hline
\end{tabular}

\subsection{Data collection procedure and analysis}

Data were collected over 2 weeks with the aid of 7 research assistants. Both written and verbal consent of all the respondents was sought and the research procedure was explained to them. The anonymity of each respondent was assured. Data collected from the field was coded and analyzed using descriptive statistics and correlation analysis at 0.05 level of confidence. Out of the 474 distributed instruments only 422 was collected and used for analysis.

\section{Findings}

\subsection{Presentation of Result}

The data analyzed was based on the answered items on the questionnaire. The questions were raised based on the objectives of the study which was to examine the extent to which the COVID-19 pandemic has affected Small and Medium Enterprises (SMEs) Data was analyzed using descriptive statistics before being subjected to parametric statistics. The analyzed data are presented in table 2-6 and figure 1-5. 
Ojong-Ejoh. et.al | Quantitative Economics and Management Studies (QEMS), 2021, 2(4): 272-280

Table 2. Responses on COVID-19 pandemic and Small and Medium Enterprises (SMEs) (1)

\begin{tabular}{clrcccccc}
\hline S/N & item & & $\begin{array}{l}\text { Food } \\
\text { \&drinks }\end{array}$ & $\begin{array}{l}\text { Animal farming } \\
\text { \&Accessories }\end{array}$ & $\begin{array}{l}\text { Electricals \& } \\
\text { Electronics }\end{array}$ & fashion & $\begin{array}{l}\text { Home } \\
\text { accessories }\end{array}$ & Manufacturing \\
\hline 1 & $\begin{array}{l}\text { What kind of } \\
\text { business do you } \\
\text { operate }\end{array}$ & $\begin{array}{c}(33.4 \%) \\
(33.4 \%)\end{array}$ & $38(9.0 \%)$ & $57(13.5 \%)$ & 83 & $87(20.6 \%)$ & $16(3.8 \&)$ \\
& & & & $(19.6 \%)$ & & \\
\hline
\end{tabular}

\section{What kind of business do you operate}

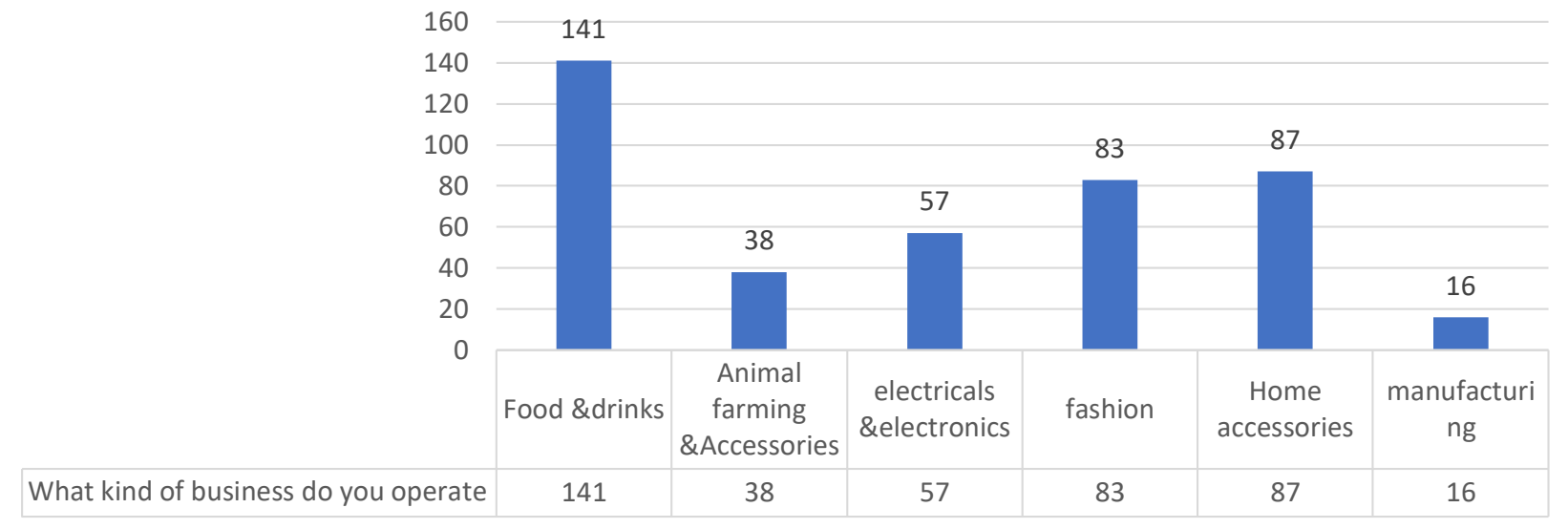

Fig. 1. The type of Business

Table 3. Responses on COVID-19 pandemic and Small and Medium Enterprises (SMEs) (2-4)

\begin{tabular}{llcccc}
\hline S/N & Items & SA & A & D & SD \\
\hline 2 & since the pandemic started and the government measures & 230 & 144 & $28(6.63)$ & $20(4.73)$ \\
& to check the spread, business have been very bad & $(54.50)$ & $(34.12)$ & & \\
3 & Purchasing goods and raw materials have been difficult & 219 & 164 & $22(5.21)$ & $17(4.03)$ \\
& & $(51.89)$ & $(38.86)$ & 52 & $36(8.53)$ \\
& & & 172 & 162 & $52.32)$ \\
\end{tabular}

Table 4. Responses on COVID-19 pandemic and Small and Medium Enterprises (SMEs) (5-6)

\begin{tabular}{llcc}
\hline S/N & Items & Yes & No \\
\hline 5 & Have employees working under me & $399(94.5 \%)$ & $23(4.5 \%)$ \\
6 & I have laid off employees since the pandemic & $301(71.3 \%)$ & $121(28.7 \%)$ \\
& started & & \\
\hline
\end{tabular}

Table 5. Responses on COVID-19 pandemic and Small and Medium Enterprises (SMEs) (7-8)

\begin{tabular}{|c|c|c|c|c|c|c|}
\hline $\mathrm{S} / \mathrm{N}$ & Item & $0-20 \%$ & $21-40 \%$ & $41-60 \%$ & $61-80 \%$ & $81-100 \%$ \\
\hline 7 & Per centage of drop in revenue & $\begin{array}{c}51 \\
(12.1 \%)\end{array}$ & $\begin{array}{c}109 \\
(25.8 \%)\end{array}$ & $\begin{array}{c}153 \\
(36.3 \%)\end{array}$ & $88(20.9 \%)$ & $21(5.0 \%)$ \\
\hline 8 & Per centage of drop in sales & $\begin{array}{c}43 \\
(10.2 \%)\end{array}$ & $\begin{array}{c}153 \\
(36.3 \%)\end{array}$ & $\begin{array}{c}157 \\
(37.2 \%)\end{array}$ & $61(14.5 \%)$ & $8(1.9 \%)$ \\
\hline
\end{tabular}


Ojong-Ejoh. et.al | Quantitative Economics and Management Studies (QEMS), 2021, 2(4): 272-280

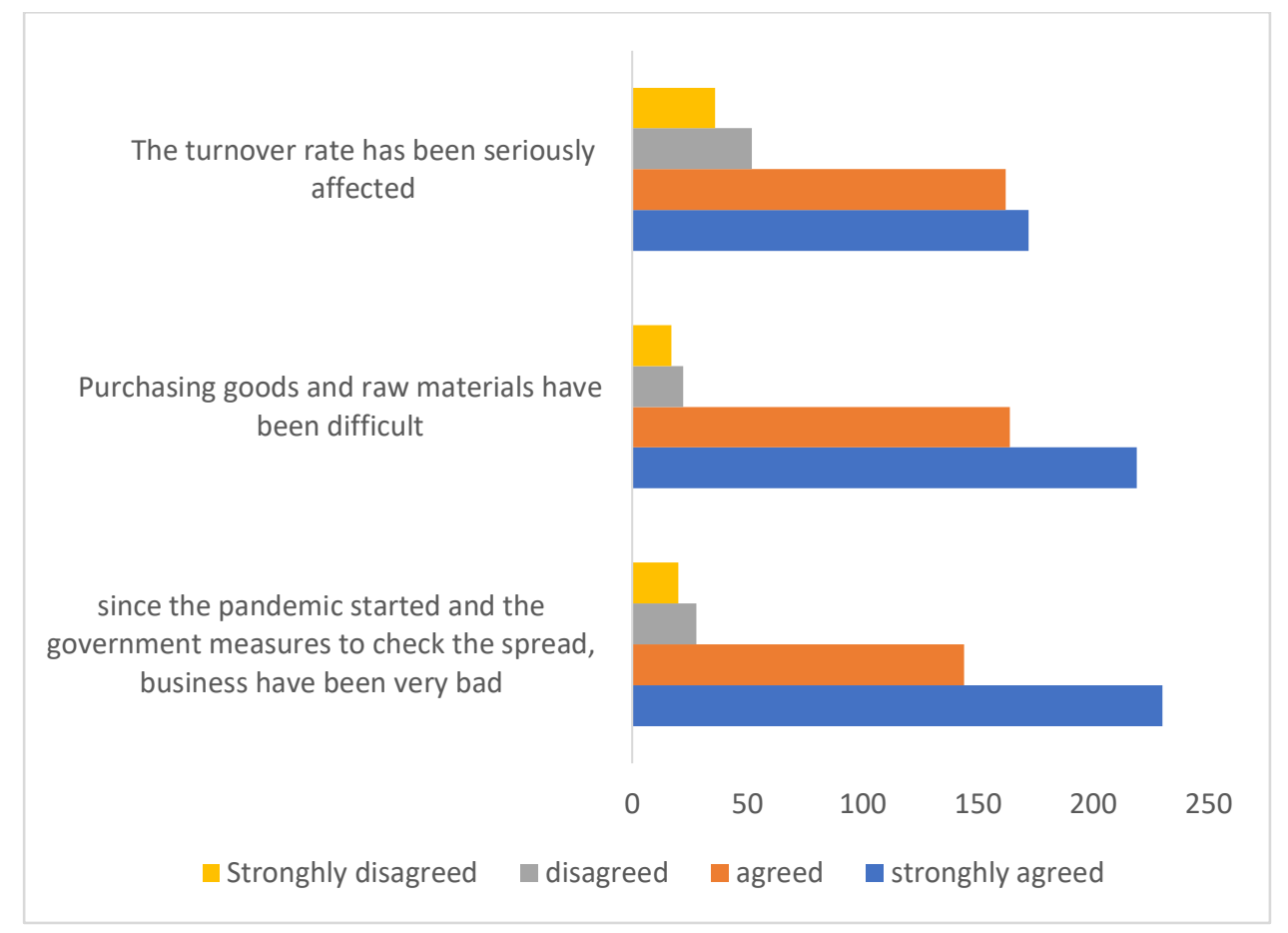

Fig. 2. COVID-19 pandemic and Small and Medium Enterprises (SMEs)

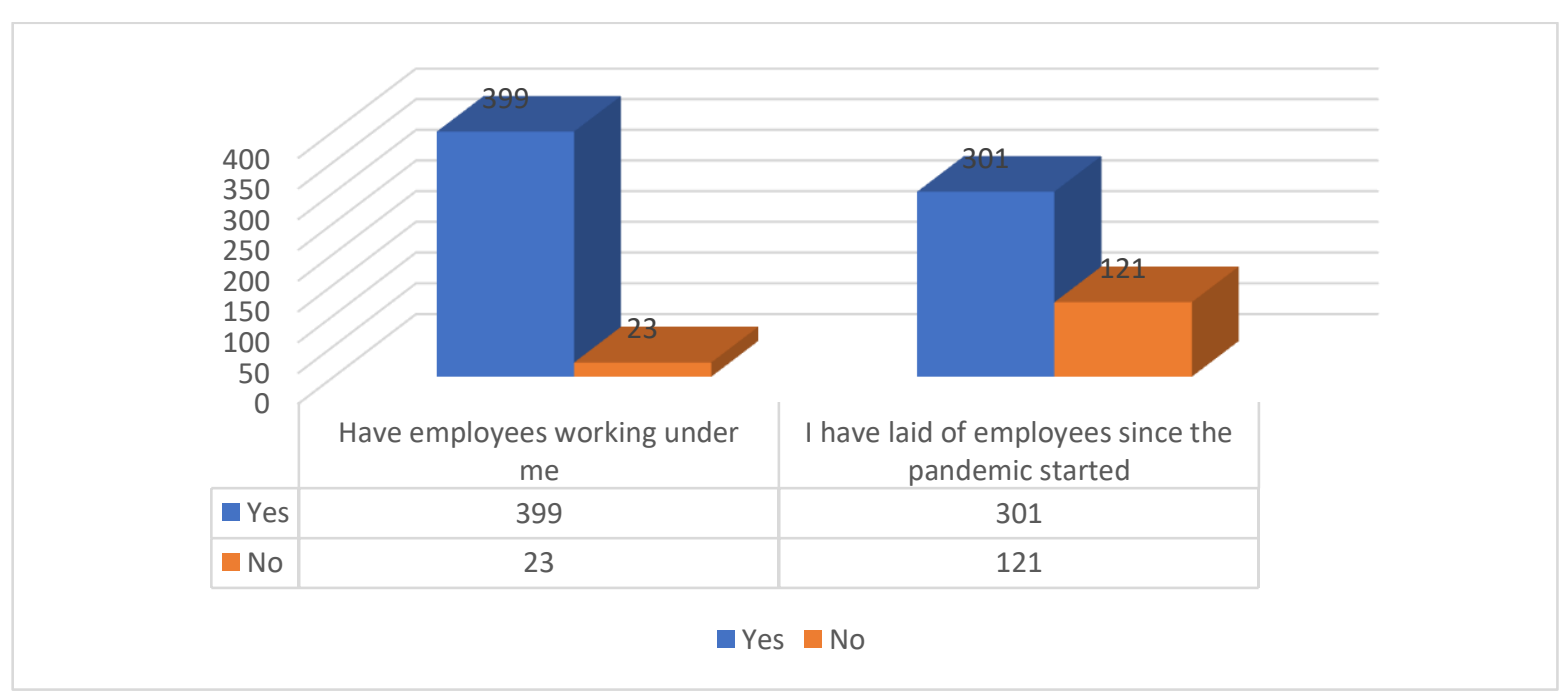

Fig. 3. Response on employees 


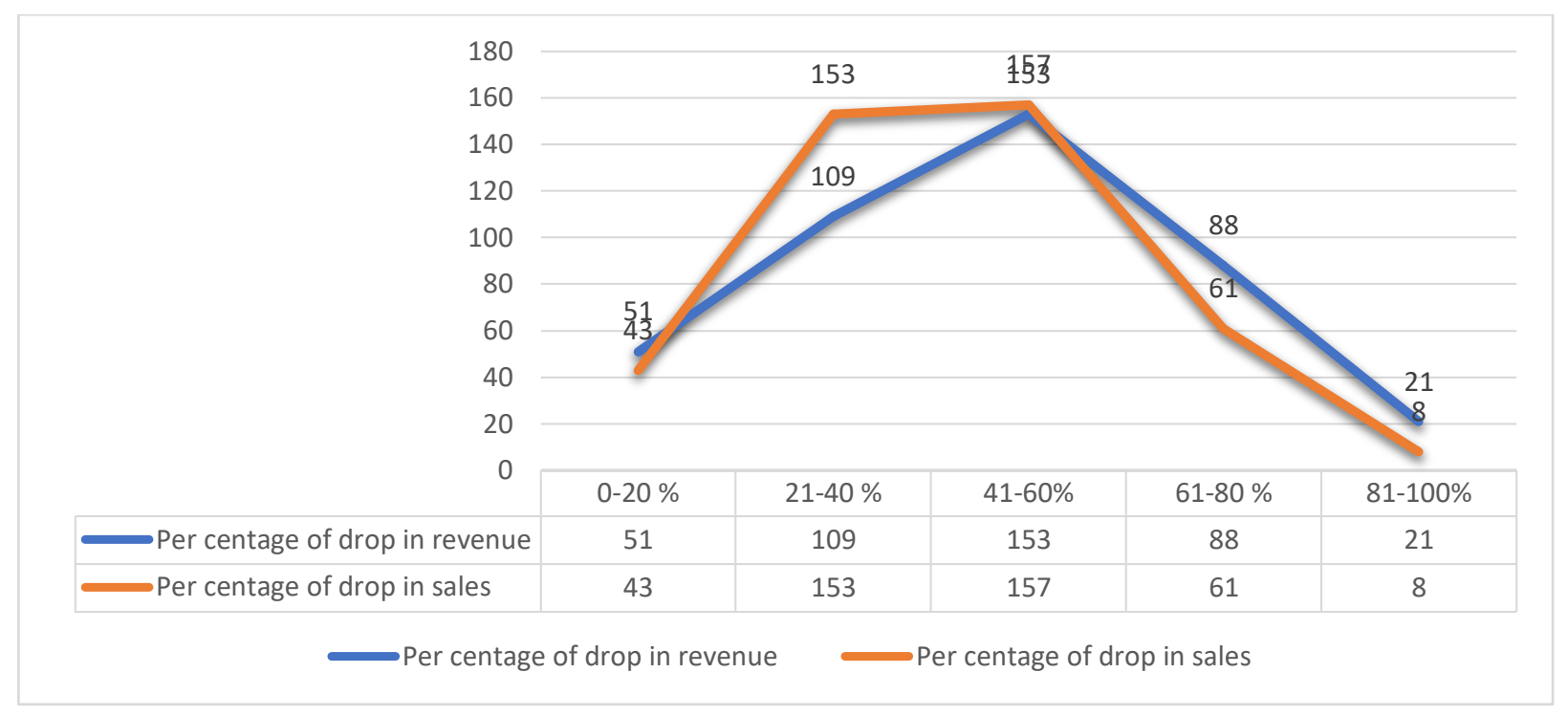

Fig. 4. Response on percentage drop in revenue and sales

Table 6. Responses on COVID-19 pandemic and Small and Medium Enterprises (SMEs)

\begin{tabular}{cccc}
\hline S/N & \multicolumn{1}{c}{ item } & Yes & No \\
\hline 9 & $\begin{array}{l}\text { Did you receive any form of government palliative to cushion the } \\
\text { effect of the pandemic measures on your business }\end{array}$ & 0 & 422 \\
\hline
\end{tabular}

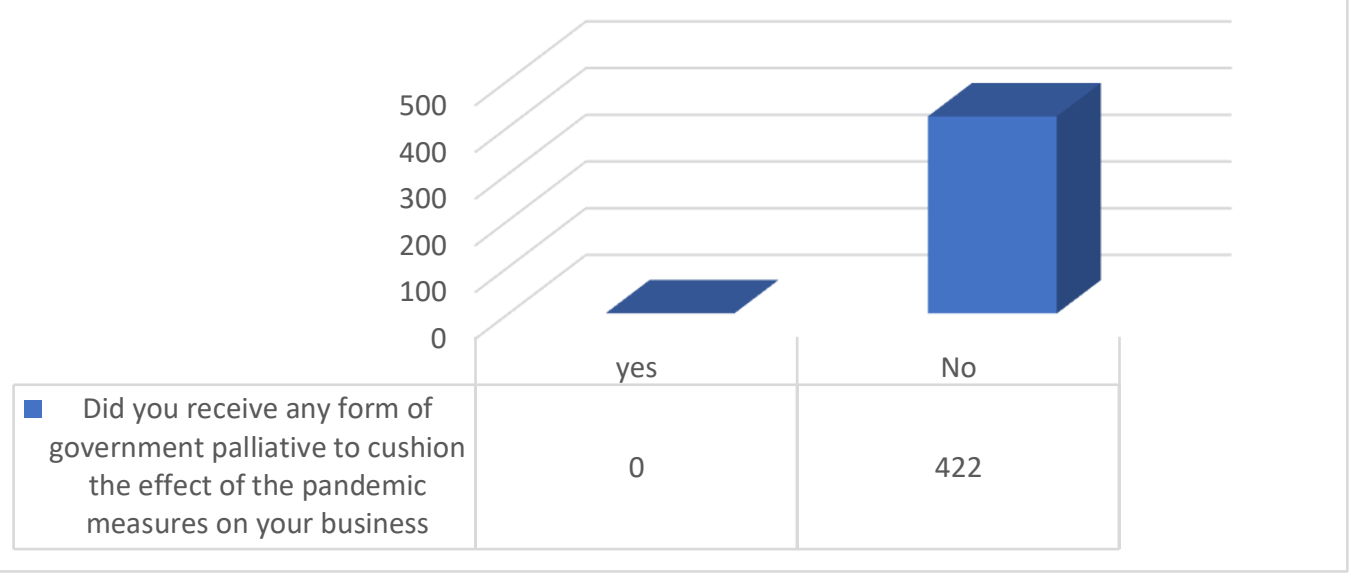

Fig. 5. Response on government palliative to cushion the effect of the pandemic measures

The result from the analyzed data as presented in table 2-6 and figure 1-5 revealed shows respondent's response pattern as follows; What kind of business do you operate; 33.4 per cent (141) food and drinks; 13.5 per cent (57) electricals and electronics; 9.0 per cent (38) animal farming and accessories; 20.6 per cent (87) home accessories, 3.8 per cent (16) manufacturing, 19.6 per cent (83) fashion. since the pandemic started and the government measures to check the spread, business have been very bad; 54.5 per cent (230) strongly agreed, 34.1 per cent (144) Agreed, 6.6 per cent (28) disagreed, 4 per cent (20) strongly disagreed. Purchasing goods and raw materials have been difficult; 51.9 per cent (219) strongly agreed, 38.9 per cent (164) agreed, 5.21 per cent (22) disagreed, 4.0 per cent (17) 
strongly disagreed. The turnover rate has been seriously affected; 40.8 per cent (172) strongly agreed, 38.4 per cent (162) agreed, 12.3 per cent (52) disagreed, 8.53 per cent (36) strongly disagreed. Have employees working under me; 94.5 per cent (399) responded yes, 4.5 per cent (23) responded No. I have laid off employees since the pandemic started; 71.3 per cent (301) responded Yes, 28.7 per cent (121) responded No. On Percentage of drop in revenue; 12.1 per cent (51) reported 0-20 per cent, 25.8 per cent (109) reported 21-40 per cent, 36.3 per cent (153) reported 4160per cent, 20.9 per cent (88) reported 61-80 per cent, 5.0 per cent (21) reported 81- 100 percent. On Percentage of drop in sales; 10.2 per cent (43) reported 0-20 per cent, 36.3 per cent (153) reported 21-40 per cent, 37.2 per cent (157) reported 41-60 per cent, 14.5 per cent (61) reported 61-80 per cent, 1.9 per cent (8) report 81-100 per cent drop in sales. Data also revealed that no of the respondent received any palliative to support their SMEs during the pandemic.

\subsection{Data Analysis}

Correlation analysis was also carried out to check the relationship (effect) of the COVID-19 Pandemic on Small and medium enterprise. For the analysis, the independent variable is COVID-19 pandemic and the dependent variable is SMEs. the analysis was carried out at 0.05 confidence level and presented in table 7 .

Table 7. Summary Pearson Product Moment Correlation analysis of COVID-19 Pandemic and Small and medium enterprise

\begin{tabular}{llllll}
\hline Variables & $\mathrm{N}$ & Mean & SD & $\mathrm{R}$ & $\mathrm{p}$-value \\
\hline $\begin{array}{l}\text { COVID-19 } \\
\text { Pandemic }\end{array}$ & 422 & 14.3743 & 4.77323 & & $.000 *$ \\
& & & & .376 & \\
$\begin{array}{l}\text { Small and } \\
\text { medium } \\
\text { enterprise }\end{array}$ & 422 & 21.6270 & 6.90593 & & \\
\hline *p<.05, df $=420$ & & & & &
\end{tabular}

The analysis result indicates that the calculated $r$-value of .376 is greater than the critical p-value of .000 at 0.05 confidence level at a degree of freedom of 420 . By this result, there is a significant correlation between COVID-19 pandemic and small and medium enterprise development in the study area.

\subsection{Discussion of Findings}

The analysis of the descriptive data elicited from the respondents revealed that most the respondents 33.4 per cent (141) operated Food and drinks enterprise, 20.6 per cent (87) operated home accessories SMEs, 19.6 per cent (83) operated fashion SMEs, 13.5 per cent (57) operated electronics and electrical enterprises, 9.0 per cent (38) operated animal family and farm accessories, 3.8 per cent (16) operated Manufacturing enterprises. From the analysis, 88.6 per cent of SMEs Operators reported that business has been very bad since the Coronavirus measures were put in place. 90.8 per cent of reported that Purchasing goods and raw materials have been difficult. 79.2 per cent reported that the turnover rate has been seriously affected. This finding is supported by the study of ITC (2020), who carried out a survey of SMES in 132 countries and found that two-thirds of small and micro firms reported been strongly affected by the coronavirus pandemic. The study by Buffington et all (2020) on the impact of COVID-19 pandemic on small business, found that 90 per cent of small business owners reported experiencing strong negative impact as a result of the pandemic, 45 per cent reported experiencing disruption in their supply chain and 25 per cent reported having less than 1-2-month cash reserve.

From the analysis, it was also discovered that 71.3 per cent of SMEs have laid off their employees as a result of the COVID-19 pandemic measures. This finding is supported by the works of Bartik et al (2020), on the effect of coronavirus measures on 5800 small businesses in the United States found that 43 per cent of small business reported closure and small businesses have reduced their employees by average 40 per cent. Mckinsey (2020) found that two out of every three jobs in SMES at risk as a result of the pandemic. 
Findings also revealed that none of the SMEs reported ever receiving any form of government palliative to cushion the effect of the pandemic measures on your business. From the correlation analysis, it was discovered that there is a significant correlation between COVID-19 pandemic and small and medium enterprise development in the study area. This is because the calculated $r$-value of .376 is greater than the critical p-value of .000 at 0.05 confidence level at a degree of freedom of 420 . With this finding, it can be concluded that the Coronavirus pandemic has seriously affected the operations of SMEs in Calabar, Cross River State, Nigeria. This is supported by that of Humphries, Nelson and Ulyssea (2020), whose survey reported that two-thirds of small business reported that the businesses have been seriously affected by the COVID-19 pandemic. The Mckinsey (2020) report indicated that 25per cent to 36per cent of SMES have been closed down globally.

\section{Conclusion and Policy Implication}

The labor and economic consequence of the Coronavirus pandemic as the findings of this study have shown has farreaching consequences on small and medium enterprise globally, undermining the operations and development of SMES and the creation of decent and sustained employment. Various efforts by the government of different nations to curb the spread of the virus has disrupted production process, reduce demands for essential service and force small business enterprise to reduce or stop their operations. Hence, The Nigerian government and its agency in charge of tax collection (federal inland revenue service) should wave the payment of tax for small and medium enterprises considering the effect the coronavirus and measures to curb it have had on the finance and operation of SMEs. The central bank should revisit their decision to increase the cash reserve ratio (CRR) from 22.5per cent to 27.5per cent to provide liquidity for banks to allow them to provide credits to the private sector.

\section{Reference}

Adah, J. A., Angioha, P. U., Ugwuonwu, C. V., \&Akomaye, S. (2020), "An Empirical Analysis of the Relationship between Working Condition and the Effectiveness of Employees in Commercial Banks in Cross River State" Journal of Banking and Finance Management, 3(2), 2020, pp. 18-24.

Akanni, L. O. \& Gabriel, S. C. (2020). The implication of COVID-19 pandemic on the Nigerian Economy. http://cseaafrica.org/the-implication-of-covid19-on-the-nigerian-economy/

Akintola, A. I., Angioha, P. U., Abang, T. \& Etta, E. (2020). COVID 19 Pandemic and Entrepreneurship Enterprise in Calabar, Cross River State, Nigeria. Conference Proceedings of the 2020 Virtual International Conference of the Research Centre for Management and Social Studies. 1, 177-183

Ali, I., \& Alharbi, O. (2020). COVID-19: Disease, management, treatment, and social impact. The Science of the total environment, 728, 138861. https://doi.org/10.1016/j.scitotenv.2020.138861

Angioha, P. U., Nwagboso, S. N., Ironbar, A. E. \& Ishie, E. U. (2018). Underemployment: A sociological and policy analysis of workers well-being in hospitality industry in Calabar, Cross River State, Nigeria. IOSR Journal of Humanities and Social Science (IOSR-JHSS), 23(6), 57-66.

Angioha, P. U., Omang, T. A., Ishie, E. U., \& Iji, M. E. (2020)., "Employee Stressors and Wellbeing of Healthcare Workers in Government owned Hospitals in Calabar, Nigeria", Journal of Public Administration, 2(4), 2020, pp. 36-43

Bartik, A. W., Bertrand, M., Cullen, Z., Glaeser, E. L., Luca, M., \& Stanton, C. (2020). The impact of COVID-19 on small business outcomes and expectations. Proceedings of the National Academy of Sciences, 202006991. DOI:10.1073/pnas.2006991117

Buffington, C. et al. (2020), "Measuring the Effect of COVID-19 on U.S. Small Businesses: The Small Business Pulse Survey", No. CES-20-16, US Census Bureau, https://www.census.gov/library/workingpapers/2020/adrm/CES-WP-20-16.html 
Ojong-Ejoh. et.al | Quantitative Economics and Management Studies (QEMS), 2021, 2(4): 272-280

Eggers, F. (2020). Masters of disasters? Challenges and opportunities for SMEs in times of crisis. Journal of Business Research, 116, 199-208. doi: 10.1016/j.jbusres.2020.05.025

Iji, M. E., Ojong, F. \& Angioha, P. U. (2018). Microfinance Credit Programmes: Implications on Poverty Reduction in Southern Senatorial District of Cross River State, Nigeria. Journal of Humanities and Social Science, $23(6), 38-45$.

International Organization for Migration (2020). Impact of COVID-19 on small and medium-sized enterprises in Iraq (June 2020). https://reliefweb.int/report/iraq/impact-COVID-19-small-and-medium-sized-enterprises-iraqjune-2020

International Trade Centre (2018). Promoting SME competitiveness in Africa: Data for de risking investment. ITC, Geneva https://www.intracen.org/uploadedFiles/intracenorg/Content/Publications/Africa_SME\%20web.pdf

ITC (2020), SME Competitiveness Outlook 2020: COVID-19: The Great Lockdown and its Impact on Small Business, ITC, Geneva, http://www.intracen.org

Li, H., Liu, S. M., Yu, X. H., Tang, S. L., \& Tang, C. K. (2020). Coronavirus disease 2019 (COVID-19): current status and future perspectives. International journal of antimicrobial agents, 55(5), 105951. https://doi.org/10.1016/j.ijantimicag.2020.105951

McKinsey (2020), Which small businesses are most vulnerable to COVID-19--and when, https://www.mckinsey.com/featured-insights/americas/which-small-businesses-are-most-vulnerableto-COVID-19-and-when

Nicola, M., Alsafi, Z., Sohrabi, C., Kerwan, A., Al-Jabir, A., Iosifidis, C., Agha, M., \& Agha, R. (2020). The socioeconomic implications of the coronavirus pandemic (COVID-19): A review. International journal of surgery (London, England), 78, 185-193. https://doi.org/10.1016/j.ijsu.2020.04.018

OECD (2019), OECD SME and Entrepreneurship Outlook 2019, OECD Publishing, Paris, https://doi.org/10.1787/34907e9c-en.

Omang, T. A., \& Angioha, P. U. (2021). Assessing the Impact COVID-19 Pandemic on the Educational Development of Secondary School Students. JINAV: Journal of Information and Visualization, 2(1), 25-32. https://doi.org/10.35877/454RI.jinav261

Omang, T. A., Angioha, P. U., Ojong-Ejoh, M. U. \& Abang, T. (2020). COVID-19 Measures and the Exacerbation of Intimate Partner Violence in Calabar, Ijo- International Journal Of Social Science And Humanities Research., 3(12)83-94

Onyinyechukwu, L. (2020). The Impact Of COVID-19 On SMEs In Nigeria. https://www.sme360.ng/2020/07/08/theimpact-of-COVID-19-on-smes-in-nigerial

Saidu, M. \& Aifuwa, H. O. (2020). Coronavirus pandemic in Nigeria: How can Small and Medium Enterprises (SMEs) cope and flatten the curve. European Journal of Accounting, Finance and Investment, 6(5), 55-61., Available at SSRN: https://ssrn.com/abstract=3621484

SUN Business Network (2020). Impacts of COVID-19 on SMEs in the food system. https://scalingupnutrition.org/news/impacts-of-COVID-19-on-smes-in-the-food-system/

Yuki, K., Fujiogi, M., \& Koutsogiannaki, S. (2020). COVID-19 pathophysiology: A review. Clinical immunology (Orlando, Fla.), 215, 108427. https://doi.org/10.1016/j.clim.2020.108427 